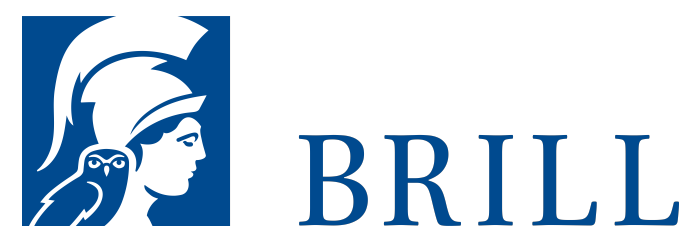

\title{
Kollektives und individuelles Bewusstsein
}

\section{Author: Karen Gloy}

Karen Gloys neues Buch geht der Funktion und Geschichte der Begriffe Individual- und Kollektivbewußtsein nach - Begriffe, die heute wegen ihrer politischsoziologischen Bedeutung und der geschichtlichen Entwicklung im 20. Jahrhunderts kaum noch unbelastet gebraucht werden können.

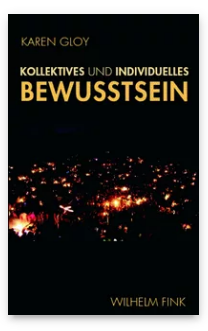

Pages: 171 Seiten

Language:

German

Subjects:

General,

Philosophy

Publisher: Brill |

Fink

E-Book (PDF)

Released online:

13 Jan 2020

ISBN: $978-3^{-}$

8467-4868-8

List price

USD $\$ 54.00$

Hardback

Publication date: o7 Oct 2009

ISBN: 978-3-

7705-4868-2

List price

USD $\$ 54.00$ 
For more information see brill.com

Order information: Order online at brill.com +44330 333 0049 | customerservices@brill.com Submission information: brill.com/authors

Titles published by Brill | Fink, Brill | mentis or Brill | Schöningh: +49(o)715413279216| brill@brocom.de 